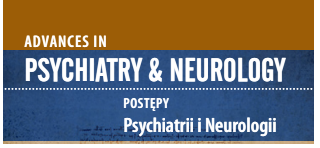

Correspondence to/
Adres do korespondencji:

Beata Łabuz-Roszak

Department of Basic Medical Sciences Faculty of Public Health in Bytom

Medical University of Silesia in Katowice

18 Piekarska St.

41-902 Bytom, Poland

e-mail: beatamaria.pl@hoga.pl

Submitted/Otrzymano: 23.03.2018

Accepted/Przyjęto do druku: 30.10.2018

\section{OPTICAL COHERENCE \\ TOMOGRAPHY IN THE DIAGNOSTICS OF NEURODEGENERATIVE DISEASES}

\section{ZASTOSOWANIE OPTYCZNEJ \\ KOHERENTNEJ TOMOGRAFII \\ W DIAGNOSTYCE CHORÓB NEURODEGENERACYJNYCH}

\author{
Magdalena Torbus-Paluszczak', Beata Łabuz-Roszak²
}

'Department and Clinic of Neurology, School of Medicine with the Division of Dentistry in Zabrze, Medical University of Silesia, Katowice, Poland ${ }^{2}$ School of Public Health in Bytom, Medical University of Silesia, Katowice, Poland

'Katedra i Klinika Neurologii, Wydział Lekarski z Oddziałem Lekarsko-

-Dentystycznym w Zabrzu, Śląski Uniwersytet Medyczny, Katowice, Polska

${ }^{2}$ Wydział Zdrowia Publicznego w Bytomiu, Śląski Uniwersytet Medyczny, Katowice, Polska

\begin{abstract}
Purpose: Review of the literature on the use of optical coherence tomography (OCT) in the diagnosis of the chosen neurodegenerative diseases - Alzheimer's disease (AD) and Parkinson's disease (PD). The review also includes multiple sclerosis (MS), where the neurodegenerative process is secondary to inflammatory-autoimmune processes.

Views: The retina is an integral part of the central nervous system (CNS), so neurodegenerative processes also affect it. The transparency of the eyeball causes the retina to be a "window into the brain" and by using OCT we can look at the CNS. Thanks to the specific structure of the retina - its lack of myelin and small number of glial cells - the progress of neurodegenerative diseases can be assessed at a very early stage and, thanks to OCT, quantified. The parameters associated in the literature with OCT - RNFL (retinal nerve fiber layer) and GCL (ganglion cell layer) - were analysed in correlation to other diagnostic examinations and functional tests in chosen diseases (AD, PD, MS). Multiple studies have also evaluated the efficacy of OCT in patients with stroke, spinal-cerebellar ataxia, obstructive sleep apnea, congenital diseases of CNS, and with prion diseases.
\end{abstract}

Conclusions: OCT is a precise additional examination that allows to assess the process of neurodegeneration at a very early stage. The results should be interpreted with reference to clinical symptoms and other diagnostic techniques.

Key words: multiple sclerosis, Parkinson's disease, Alzheimer's disease, neurodegeneration, optical coherent tomography.

\title{
Streszczenie
}

Cel: Przegląd piśmiennictwa w zakresie wykorzystania optycznej koherentnej tomografii (OCT) w diagnostyce wybranych chorób neurodegeneracyjnych - choroby Alzheimera (AD) oraz choroby Parkinsona (PD). W przeglądzie uwzględniono również stwardnienie rozsiane (SM), gdzie proces neurozwyrodnieniowy jest wtórny do procesów zapalno-autoimmunologicznych.

Poglądy: Siatkówka stanowi integralną część ośrodkowego układu nerwowego (OUN), której także dotyczą procesy neurodegeneracyjne. Przezierność gałki ocznej sprawia, że siatkówka stanowi „okno”, przez które można ocenić OUN. Dzięki jej specyficznej budowie - braku mieliny i niewielkiej ilości komórek glejowych - istnieje możliwość wykrycia bardzo wczesnych zmian w chorobach neurodegeneracyjnych, a badanie OCT umożliwia również ilościową ocenę. W licznych pracach badawczych analizowano parametry: RNFL (warstwa włókien nerwowych siatkówki) i GCL (warstwa komórek zwojowych). Odnoszono je do innych badań diagnostycznych i testów funkcjonalnych w wybranych chorobach (AD, PD, SM). Niektórzy badacze oceniali również przydatność diagnostyczną OCT u pacjentów po udarze mózgu, z ataksją rdzeniowo-móżdżkową, wrodzonymi schorzeniami OUN, obstrukcyjnym bezdechem sennym i chorobami prionowymi.

Wnioski: OCT jest precyzyjnym, nieinwazyjnym badaniem dodatkowym, które pozwala ocenić procesy neurodegeneracji na bardzo wczesnym etapie. Jednakże wyników nie można interpretować bez odniesienia do objawów klinicznych i innych badań diagnostycznych. Słowa kluczowe: stwardnienie rozsiane, choroba Parkinsona, choroba Alzheimera, neurodegeneracja, optyczna koherentna tomografia. 
Optical coherence tomography in the diagnostics of neurodegenerative diseases

Zastosowanie optycznej koherentnej tomografii w diagnostyce chorób neurodegeneracyjnych

\section{INTRODUCTION}

Indications for the implementation of optical coherence tomography (OCT) in ophthalmic practice are primarily diseases that cause degeneration in the retina and macula, i.e. glaucoma, age-related macular degeneration (AMD), diabetic maculopathy, macular edema and tumors, and central serous retinopathy. The use of OTC has been a revolutionary solution not only in ophthalmology. It has also become an important tool in neurological practice, especially in the diagnostics of neurodegenerative diseases. The increasingly common implementation of the method has triggered multiple investigations aimed at understanding the pathophysiology and courses of such diseases.

The retina and the optic nerve are elements of the central nervous system (CNS). They comprise three types of neurons: photoreceptors, bipolar cells and ganglion cells, which form the visual pathway [1]. Located among these are amacrine and horizontal cells, modulation signals of intracellular transmission [2]. The layer of retinal nerve fibres (RNFL)t is composed of the unmyelinated axons of ganglion cells, acquiring the myelin sheath only as they leave the eyeball to form the optic nerve. The translucency of the eyeball ensures that the retina is a "window" through which we can have insight into the CNS [3]. The absence of myelin and low retina concentration of glia cells form excellent conditions for the assessment of neurodegeneration.

OCT is a non-invasive diagnostic method which allows for the in vivo evaluation of tissue sections at very high resolution. The images of cross-sections are produced by adding multiple axial depths of optic wave reflection (A-scans). The image quality depends on the scanning rate and resolution [4]. The first OCT devices scanned at 400 scans/minute with resolution of 8-10 $\mu \mathrm{m}$, ensuring insight into all layers of the retina. The OCT scanners currently in use operate at 20,00052,000 scans per minute with a resolution of $1-4 \mu \mathrm{m}$. Their higher scanning rates reduce multiple kinetic artefacts, while high resolution provides for imaging not only at the tissue but also the cellular level [5].

Thanks to OCT it is then possible to obtain quickly and precisely an image of the retina at close to microscopic resolution, preventing also any risk of dangerous radiation.

\section{OPTICAL COHERENCE TOMOGRAPHY IN ALZHEIMER'S DISEASE}

Alzheimer's disease (AD) is the most prevalent progressive neurodegenerative condition resulting in dementia. The underlying mechanism is the accumulation of beta-amyloid in the form of plaque deposition and

\section{WSTĘP}

Wskazaniem do wykonania optycznej koherentnej tomografii (optical coherence tomography - OCT) siatkówki w praktyce okulistycznej są przede wszystkim schorzenia powodujące zwyrodnienie w obrębie siatkówki i plamki, tj. jaskra, zwyrodnienie plamki żółtej (age-related macular degeneration - AMD), makulopatia cukrzycowa, obrzęki i nowotwory plamki, centralna retinopatia surowicza. Wykorzystanie OCT zrewolucjonizowało nie tylko okulistykę, ale stało się ważnym narzędziem w praktyce neurologicznej, a zwłaszcza w diagnostyce chorób neurozwyrodnieniowych. Powszechne używanie OCT rozpoczęło erę badań wykorzystujących tę metodę do zrozumienia patofizjologii i przebiegu tych chorób.

Siatkówka i nerw wzrokowy są częścią ośrodkowego układu nerwowego (OUN). Znajdują się tu 3 typy neuronów: fotoreceptory, komórki dwubiegunowe i komórki zwojowe, które tworzą drogę wzrokową [1]. Między nimi leżą komórki amakrynowe i komórki poziome, modulujące sygnały transmisji międzykomórkowej [2]. Warstwa włókien nerwowych siatkówki (retinal nerve fiber layer RNFL) składa się z niezmielinizowanych aksonów komórek zwojowych, które mielina pokrywa dopiero, gdy opuszczają gałkę oczną, tworząc nerw wzrokowy. Przezierność gałki ocznej powoduje, że siatkówka jest „oknem”, przez które możemy spojrzeć na ośrodkowy układ nerwowy [3]. Idealne warunki do oceny chorób neurodegeneracyjnych stwarza brak mieliny i niska koncentracja komórek glejowych w siatkówce.

Badanie OCT jest nieinwazyjną metodą diagnostyczną, która pozwala na badanie in vivo przekrojów tkanek w bardzo dobrej rozdzielczości. Obrazy przekrojów poprzecznych są tworzone przez zsumowanie licznych osiowych głębokości odbicia fal świetlnych (A-scans). Jakość obrazu zależy od szybkości skanowania i rozdzielczości [4]. Pierwsze aparaty OCT skanowały z szybkością 400 skanów/minutę, miały rozdzielczość $8-10 \mu \mathrm{m}$ i pozwalały zbadać w głąb wszystkie warstwy siatkówki. Nowoczesne aparaty OCT mogą już pracować z szybkością 20 000-52 000 skanów/minutę i w rozdzielczości 1-4 $\mu \mathrm{m}$. Większa szybkość skanowania pozwala zredukować liczne artefakty ruchowe, podczas gdy duża rozdzielczość umożliwia przeprowadzenie badania nie tylko na poziomie tkankowym, ale i komórkowym [5].

Dzięki OCT można szybko i dokładnie, z niemal mikroskopową rozdzielczością, uzyskać obraz siatkówki, unikając przy tym niebezpiecznego promieniowania.

\section{OPTYCZNA KOHERENTNA TOMOGRAFIA W CHOROBIE ALZHEIMERA}

Choroba Alzheimera (Alzheimer's disease - $\mathrm{AD}$ ) to najczęstsza postępująca choroba neurodegeneracyjna. Jej osiowym objawem jest otępienie. W chorobie tej dochodzi do akumulacji w mózgu beta-amyloidu w postaci plak 
the formation of neurofibrillary tangles containing tau protein in the CNS [6]. AD patients frequently complain of visual disturbances, which are associated with the presence of beta-amyloid deposits in the visual pathway, reduced circulation in retina vessels, vacuolar degeneration of ganglion cells and their axons within the optic nerve, lower retinal nerve fibre layer thickness (RNFL-th) and atrophy of neurons in the occipital lobe [7]. The results of the research on ophthalmic symptoms in $\mathrm{AD}$ are ambiguous. In the early stages of the disease, visual acuity is normal. At the later stage it is difficult to assess. Impaired colour vision can affect up to $50 \%$ of patients. Patients with $\mathrm{AD}$ are less likely to deal with tasks in which colour plays a key role. There are also defects in the view field mainly in the lower quadrants and a lowering of the sensitivity of contrast in the entire spatial frequency range [8].

Multiple hypotheses have been put forward regarding reduced RNFL-th in AD. One author indicated that degenerative processes in $\mathrm{AD}$ affect not only the cortex, but also the retina. The number of ganglion cells may be reduced by as much as $36.4 \%$ [9]. Similarly to the cortex, beta-amyloid and tau protein are also accumulated between the layers of the retina and the optic nerve, as they are in the cortex [10]. Another hypothesis focuses on secondary neuronal injury of the retina neurons in the mechanism of retrograde trans-synaptic degeneration from the corticogeniculate pathway towards the retinogeniculate pathway and subsequent degeneration along the corticogeniculate pathway [11].

RNFL-th reduction has already been observed in mild cognitive impairment (MCI). Moreover, reduction of RNFL thickness, of the macular volume and thickness of the ganglion cell layer (GCL-th), may take place without any changes in visual acuity or area [12]. A meta-analysis concerning $\mathrm{AD}$ patients found a statistically significant loss of RNFL thickness in all quadrants [13]. Reduction in macular volume and GCL thickness were also observed $[14,15]$. All those parameters were reduced along the progressing dementia, which correlates with the Mini-Mental State Examination score (MMSE). Another meta-analysis showed the average loss of RNFL-th in AD patients reaching $11 \mu \mathrm{m}$ [16]. Impairments of the lower part of the visual area corresponded to greater reduction in RNFL thickness in the upper part of the retina [17]. No correlation was observed between RNFL-th and VEP investigations [18]. In recent years it has been possible to detect mild cognitive impairment (MCI) quite early as a result of neuropsychological research. RNFL assessment may be useful in monitoring people at increased risk of MCI and AD. Taking advantage of neuropsychological investigations, Alzheimer's disease is nowadays detected at a very early stage. Early diagnosis is also needed in individuals showing good cognitive function, however oraz powstania włókien neurofibrylarnych (neurofibrillary tangles) zawierających białko tau [6]. Zaburzenia widzenia są częstą skargą chorych na $\mathrm{AD}$ i są związane z obecnością złogów beta-amyloidu w drodze wzrokowej, zmniejszonym przepływem w naczyniach siatkówki, zwyrodnieniem wodniczkowym komórek zwojowych i ich aksonów w obrębie nerwu wzrokowego, zmniejszeniem grubości warstwy włókien nerwowych siatkówki (retinal nerve fiber layer thickness - RNFL-th) oraz zanikiem neuronów w płacie potylicznym [7]. Wyniki badań dotyczące objawów okulistycznych w AD są niejednoznaczne. We wczesnej fazie choroby ostrość wzroku jest prawidłowa, a w późniejszym stadium jest trudna do oceny. Upośledzenie widzenia barw może dotyczyć nawet $50 \%$ chorych. Chorzy z AD gorzej radzą sobie z zadaniami, w których kluczową rolę odgrywa kolor. Występują też ubytki pola widzenia, głównie $\mathrm{w}$ dolnych kwadrantach, i obniżenie czułości kontrastu w całym zakresie częstotliwości przestrzennych [8].

Istnieje wiele hipotez dotyczących zmniejszenia RNFL-th $\mathrm{w}$ AD. Jedna $\mathrm{z}$ nich mówi o tym, że procesy zwyrodnieniowe $\mathrm{w} \mathrm{AD}$ nie dotyczą tylko kory, ale również siatkówki. Redukcja liczby komórek zwojowych może sięgać do 36,4\% [9]. Między poszczególnymi warstwami siatkówki i nerwu wzrokowego dochodzi do nagromadzenia beta-amyloidu i białka tau, podobnie jak ma to miejsce w korze mózgu [10]. Inna hipoteza skupia się na wtórnym uszkodzeniu neuronów siatkówki w mechanizmie wstecznej transsynaptycznej degeneracji od szlaku kolankowato-korowego do szlaku siatkówkowo-kolankowatego z następczą degeneracją w drodze korowo-kolankowatej [11].

Redukcja RNFL-th jest już obserwowana na wczesnych etapach AD - w łagodnych zaburzeniach poznawczych (mild cognitive impairment - MCI). Ponadto zmniejszenie grubości RNFL oraz objętości plamki i grubości warstwy komórek zwojowych (ganglion cell layer thickness - GCL-th) może zachodzić bez zmian w ostrości wzroku czy w polu widzenia [12]. Na podstawie przeprowadzonej metaanalizy oceniającej pacjentów z AD stwierdzono znaczący statystycznie ubytek grubości RNFL we wszystkich kwadrantach [13]. Obserwowano również zmniejszenie objętości plamki i grubości GCL $[14,15]$. Wszystkie te parametry ulegały redukcji wraz z postępem otępienia, a korelowano je z wynikami Krótkiej Skali Oceny Stanu Psychicznego (Mini-Mental State Examination - MMSE). Z innej metaanalizy wynika, że przeciętny ubytek RNFL-th u pacjentów z AD wynosi $11 \mu \mathrm{m}$ [16]. Zaburzenia dolnej części pola widzenia korespondowały ze zwiększoną redukcją RNFL-th w górnej części siatkówki [17]. Nie wykazano korelacji między RNFL-th a badaniem wzrokowych potencjałów wywołanych (visual evoked potential - VEP) [18]. $\mathrm{W}$ ostatnich latach, dzięki badaniom neuropsychologicznym, łagodne zaburzenia poznawcze (MCI) wykrywa się dość wcześnie. Ocena RNFL może być przydatna w monitorowaniu osób obciążonych zwiększonym ryzykiem 
burdened with high risk of MCI and AD. Prompt intervention may in such cases delay or prevent progression. Recently it has even been suggested that retinal plaques may be discovered even before the onset of dementia or MCI. OCT may prove valuable as a technique of investigation that can supplement other neuropsychological tests, capable as it is of detecting the disease at a very early stage [19].

\section{OPTICAL COHERENCE TOMOGRAPHY IN PARKINSON'S DISEASE}

Parkinson's disease (PD) is a progressive neurodegenerative condition of unknown cause. Loss of dopaminergic neurons in the substantia nigra and other areas of the CNS are manifested by multiple motor symptoms [20]. The retinal amacrine cells are the major dopaminergic neurons [21], transmitting the horizontal impulses between bipolar, ganglion and other amacrine cells. The lack of dopamine results in blurred vision, impairment of colour vision or visual contrast sensitivity [22]. The following have been described in PD patients: dry eye syndrome, double vision, difficulties in reading, problems with visual fixation, and hallucinations [23]. Visual hallucinations occur in the course of dementia and are a common complication of the use of levodopa preparations. Often, in the advanced form of PD, they occur due to a reduced level of dopamine prior to the next dose of the drug being taken. There are also hallucinations associated with incorrect spectacle correction. Interestingly, most patients with PD show visual area impairment similar to that in patients with glaucoma, although their intraocular pressure (IOP) and RNFL are normal [24].

OCT was first used in 2004 to evaluate RNFL in patients with Parkinson's disease [25]. A meta-analysis, comprising 13 studies (evaluating a total of $644 \mathrm{PD}$ patients), showed a statistically significant reduction in RNFL thickness in PD patients in all quadrants, as compared to the controls [26]. Apart from this substantial reduction in RNFL-th, the studies pointed also to reduced GCL in the external as well as internal plexiform layer [23]. On the other hand, the inner nuclear layer, containing the bipolar, amacrine, horizontal and Müller cells, grows [23]. Patients with atypical Parkinsonism showed some other characteristic changes in their retinal architecture [27]. A thickening of the outer nuclear layer was observed in supranuclear paralysis, and a thickening of the outer plexiform layer in multiple system atrophy. The total thickness of the retina decreases in both diseases [27].

Shrier et al. observed interocular asymmetry of foveal thickness in their results [28]. Altintas et al. [29] wystąpienia MCI i AD. Szybka interwencja u tych osób może znacząco opóźnić początek choroby lub spowolnić jej przebieg. Ostatnio nawet zachęca się, aby w siatkówce poszukiwać plak, które mogą pojawiać się przed wystąpieniem zaburzeń poznawczych. Tomografia OCT może być wartościowym badaniem, które w połączeniu $\mathrm{z}$ oceną neuropsychologiczną pomaga wykryć chorobę już na bardzo wczesnym etapie [19].

\section{OPTYCZNA KOHERENTNA TOMOGRAFIA W CHOROBIE PARKINSONA}

Choroba Parkinsona (Parkinson's disease - PD) jest postępującą chorobą neurodegeneracyjną o nieznanej przyczynie. Ubytek dopaminergicznych neuronów w istocie czarnej i innych obszarach mózgu odpowiada za charakterystyczne dla PD objawy ruchowe [20]. W siatkówce komórki amakrynowe są głównymi dopaminergicznymi neuronami [21]. Przekazują one poziomo impulsy między komórkami dwubiegunowymi, zwojowymi i innymi komórkami amakrynowymi. Brak dopaminy skutkuje zaburzeniami widzenia centralnego, upośledzeniem widzenia barwnego oraz czułości kontrastu [22]. U chorych na PD opisywane są: zespół suchego oka, podwójne widzenie, trudności z czytaniem, problemy z fiksacją wzroku i halucynacje wzrokowe [23]. Halucynacje wzrokowe zdarzają się w przebiegu otępienia, są także częstym powikłaniem stosowania preparatów lewodopy. Często w zaawansowanej postaci PD występują w związku z obniżonym stężeniem dopaminy przed przyjęciem kolejnej dawki leku. Istnieją też halucynacje związane z nieprawidłową korekcją okularową. Interesujące jest również to, że większość chorych z PD ma zaburzenia pola widzenia podobne do tych, które występują u chorych na jaskrę, mimo że ich ciśnienie śródgałkowe i RNFL są w granicach normy [24].

Pierwszy raz metodę OCT zastosowano u pacjentów z PD w 2004 roku [25]. Na podstawie metaanalizy wykazano istotne statystycznie zmniejszenie RNFL $u$ chorych z PD we wszystkich kwadrantach w porównaniu z grupą kontrolną [26]. Poza znaczącą redukcją RNFL-th opisano również redukcję GCL i warstwy splotowatej wewnętrznej i zewnętrznej [23]. Zwiększeniu ulega natomiast warstwa jądrzasta wewnętrzna, gdzie znajdują się komórki dwubiegunowe, amakrynowe, horyzontalne i komórki Müllera [23]. U pacjentów $\mathrm{z}$ atypowym parkinsonizmem wykryto inne charakterystyczne zmiany architektoniczne siatkówki [27]. W postępującym porażeniu nadjądrowym wykazano pogrubienie zewnętrznej warstwy jądrzastej, a w zaniku wieloukładowym - pogrubienie zewnętrznej warstwy splotowatej [27]. Całkowita grubość siatkówki zmniejsza się w obu chorobach [27].

$\mathrm{Z}$ badań Shrier i wsp. wynika, że u połowy chorych na PD występuje asymetria międzyoczna w wynikach grubości dołka środkowego siatkówki [28]. Altintas i wsp. [29] 
showed a correlation between foveal thickness and the Unified Parkinson's Disease Rating Scale (UPDRS), while Satue et al. [30] pointed to a significant correlation between RNFL and UDPRS. Ahn et al. [31] showed a thinning of the retina in the lower and temporal sectors (most evident in the IPL and GCL) in PD patients who were not treated. They also confirmed the relationship between retinal thinning and the loss of dopaminergic neurons in the substantia nigra. In other works, the characteristic asymmetric loss of the retinal nerve fiber layer is described, more visible in the eye opposite to the most affected side of the body [28]. Although the knowledge of neurodegenerative processes in $\mathrm{PD}$ is relatively large, the mutual relations between amacrine cells, the dopamine level and the loss of ganglion cells remain unknown.

\section{OPTICAL COHERENCE TOMOGRAPHY IN MULTIPLE SCLEROSIS}

Multiple sclerosis (MS) is a chronic, autoimmunological disease of the central nervous system. A characteristic pathophysiological feature of the disease is the presence of inflammatory and demyelination changes, leading to axonal and neuronal degeneration. MS changes often affect the initial fragment of the visual pathway, typically under the clinical form of optic neuritis $(\mathrm{ON})$. ON is manifested by blurred, out-of-focus vision and characteristic retro ocular pain, which in about $20 \%$ of patients is the first symptom of MS. ON usually subsides partially or completely after a few months following its onset. It is estimated that approx. 50\% of patients will then develop MS [32]. Parisi et al. were the first to use OCT to examine MS patients with a history of ON [33]. They showed loss of RNFL-th of $46 \%$ in the eyes affected by ON, as compared to the controls, and a reduction of RNFL by $28 \%$ when comparing the eye with ON to the healthy eye in the same patient [33]. Recurrent ON reduces significantly the RNFL-th, as compared to eyeballs with only one ON episode $(64.2 \mu \mathrm{m}$ vs $86.3 \mu \mathrm{m}, p<0.0001$ ) [34]. Balcer [35] pointed to the difference between RNFL-th in patients with MS $(95.5 \mu \mathrm{m}$ $\pm 14.5 \mu \mathrm{m})$, as compared to the controls $(104.5 \mu \mathrm{m}$ $\pm 10.7 \mu \mathrm{m})$, and MS patients with a history of ON $(85.7 \mu \mathrm{m}$ $\pm 19.0 \mu \mathrm{m})$. Macular volume loss in ON eyes, as compared to normal eyeballs, was also observed [36]. It should be remembered that during the acute phase of $\mathrm{ON}$, RNFL-th may grow in as many as $82 \%$ of cases [37]. This is most probably because of the inflammatory condition and macular oedema [38]. Decreased RNFL is observed after a few months.

Post-mortem examination of MS patients has revealed damage of the optic nerve in $94-99 \%$ of sufferers, even if they had no clinical episode of ON $[39,40]$. De- wykazali korelację pomiędzy grubością dołka środkowego (foveal thickness) a wynikami Ujednoliconej Skali Oceny Choroby Parkinsona (Unified Parkinson's Disease Rating Scale - UPDRS), natomiast Satue i wsp. [30] - istotną korelację między RNFL a UPDRS. Ahn i wsp. [31] zaobserwowali ścieńczenie siatkówki w dolnych i skroniowych sektorach okołodołkowych (najbardziej widoczne w IPL i GCL) u chorych na PD, którzy nie byli leczeni. Potwierdzili również zależność między ścieńczeniem siatkówki a utratą neuronów dopaminergicznych w istocie czarnej. W innych pracach opisywana jest charakterystyczna asymetryczna utrata warstwy włókien nerwowych siatkówki, bardziej widoczna w oku przeciwnym do najbardziej dotkniętej chorobą strony ciała [28]. W dalszym ciągu nie są do końca jasne wzajemne zależności między komórkami amakrynowymi, poziomem dopaminy i ubytkiem komórek zwojowych.

\section{OPTYCZNA KOHERENTNA TOMOGRAFIA W STWARDNIENIU ROZSIANYM}

Stwardnienie rozsiane (łac. sclerosis multiplex - SM) jest przewlekłą, autoimmunologiczną chorobą OUN. Charakterystyczną cechą patofizjologiczną tej choroby są zmiany zapalne i demielinizacyjne, prowadzące do aksonalnej i neuronalnej degeneracji. W SM zmiany obejmują często początkowy fragment drogi wzrokowej w postaci zapalenia nerwu wzrokowego (optic neuritis - ON). Zapalenie nerwu wzrokowego objawia się zamazanym, nieostrym widzeniem oraz charakterystycznym zagałkowym bólem. W około $20 \%$ przypadków zapalenie nerwu wzrokowego stanowi pierwszy objaw SM. Przeważnie ON ustępuje częściowo lub całkowicie w ciągu kilku miesięcy od wystąpienia. U około $50 \%$ pacjentów z ON w późniejszym okresie rozwinie się SM [32]. Po raz pierwszy OCT w ocenie chorych na SM z przebytym ON zastosowali Parisi i wsp. [33]. Badanie wykazało 46-procentowy ubytek RNFL-th w oczach zajętych przez ON w porównaniu z grupą kontrolną oraz 28-procentową redukcję RNFL w oku po przebytym $\mathrm{ON}$ w odniesieniu do oka zdrowego u tego samego pacjenta [33]. Nawracające ON znacząco wpływają na zmniejszenie RNFL-th w porównaniu z oczami po jednym epizodzie ON $(64,2 \mu \mathrm{m} v s 86,3 \mu \mathrm{m} ; p<0,0001)$ [34]. Balcer [35] wykazał różnicę między RNFL-th u pacjentów z SM $(95,5 \mu \mathrm{m} \pm 14,5 \mu \mathrm{m})$ a RNFL w grupie kontrolnej $(104,5 \mu \mathrm{m}$ $\pm 10.7 \mu \mathrm{m}$ ) oraz u chorych z SM i dodatnim wywiadem w kierunku ON $(85,7 \mu \mathrm{m} \pm 19,0 \mu \mathrm{m})$. Zaobserwowano również ubytek objętości plamki żółtej w oczach po przebytym ON w porównaniu z oczami zdrowymi [36]. Należy pamiętać, że podczas ostrej fazy ON RNFL-th może wzrastać aż w $82 \%$ przypadków [37]. Uważa się, że spowodowane jest to stanem zapalnym i obrzękiem plamki [38]. Natomiast spadek RNFL zauważalny jest dopiero po kilku miesiącach.

$\mathrm{W}$ analizie pośmiertnej u chorych na SM wykazano uszkodzenie nerwów wzrokowych w 94-99\% przypadków, 
myelination of the optic nerve axons leads to primary axonal thinning and secondary degeneration of the optic nerve with further degeneration of the ganglion cells. OCT reflects those as a thinning of RNFL and macular GCL [41]. The aetiology of axonal atrophy and GCL loss in MS without ON remain unknown. Most likely, it is associated with retrograde trans-synaptic degeneration of the retinal neurons. Gundogan et al. examined 39 MS patients with no history of visual disturbances, showing a significant reduction in RNFL-th only in the temporal quadrants [42]. Other studies point to a thinning of all quadrants [43], either temporal and lower [44] or upper and lower [45]. RNFL-th has been evaluated also in different subtypes of MS. In secondary progressive MS (SPMS) the approximate value was $84.7 \mu \mathrm{m}$, as compared to clinically isolated syndrome (CIS), where it scored $105.7 \mu \mathrm{m}$ [34]. Pulicken et al. [46] indicated reduced RNFL-th in patients with relapsing-remitting MS (RRMS) of up to $94.4 \mu \mathrm{m}$, up to $88.9 \mu \mathrm{m}$ in primary progressive MS (PPMS), and up to $81.8 \mu \mathrm{m}$ in SPMS.

Based on the histological assessment of the retina, and confirmed by OCT, it has been shown that the internal nucleated layer in the eyes after $\mathrm{ON}$ in patients with MS is reduced by $40 \%$ compared to healthy eyes. In addition, the degree of retinal atrophy corresponds to the loss of cortical volume [47]. As supported by the studies, the evaluation of GCL and IPL (inner plexiform layer) may provide a more sensitive prognosis of axonal damage than evaluation of RNFL alone [24]. In their meta-analysis Brite et al. [48] showed that GCIPL (a parameter linking the values of GCL and IPL) was significantly lower in the eyes of patients with MS and a history of ON, by $16.72 \mu \mathrm{m}$, while in those with no history of ON the parameter also decreased (by $6.57 \mu \mathrm{m}$ as compared to the controls). GCL thinning may arise from a subclinical episode of $\mathrm{ON}$, a primary neurodegeneration of ganglion cells and their axons, or retrograde trans-synaptic neurodegeneration of ganglion cells and their axons in the course of damage to the end section of the visual pathway. These results prove the fact that the visual pathway may be damaged in the course of MS, even without any clinical manifestations. In their study, Brite et al. [48] observed also the correlation between decreased GCIPL and greater disability of the patient, as evaluated with the use of the Expanded Disability Status Scale (EDSS). This points to GCIPL as a potential marker of neurodegeneration.

Multiple studies have also assessed the efficacy of OCT evaluation in patients with stroke, spinal-cerebellar ataxia, obstructive sleep apnea, congenital diseases of the CNS, and with prion diseases [49-52]. nawet jeśli nie przebyli oni klinicznego epizodu ON [39, 40]. Demielinizacja nerwu wzrokowego prowadzi do pierwotnego ścieńczenia aksonów i wtórnej degeneracji nerwu wzrokowego z dalszą degeneracją komórek zwojowych. Odzwierciedla to w OCT ścieńczenie RNFL i plamkowego GCL [41]. Etiologia aksonalnego zaniku i ubytku GCL w SM bez ON jest nieznana. Prawdopodobnie jest to związane ze wsteczną transsynaptyczną degeneracją neuronów siatkówki. Gundogan i wsp. przebadali 39 chorych na SM bez zaburzeń widzenia w wywiadzie. Wykazali znaczącą redukcję RNFL-th tylko w kwadrantach skroniowych [42]. Inne badania wskazują na ścieńczenie wszystkich kwadrantów [43] bądź tylko skroniowych i dolnych [44] albo górnych i dolnych [45]. RNFL-th oceniano $\mathrm{w}$ różnych podtypach SM. W postaci wtórnie postępującej (secondary progressive multiple scerosis - SPMS) wartość ta wynosiła średnio $84,7 \mu \mathrm{m}$, a w klinicznie izolowanym zespole (clinically isolated syndrome - CIS) - 105,7 $\mu \mathrm{m}$ [34]. Pulicken i wsp. [46] wykazali zmniejszenie RNFL-th u chorych $\mathrm{z}$ postacią nawracająco-zwalniającą SM do $94,4 \mu \mathrm{m}$, pierwotnie postępującą - do $88,9 \mu \mathrm{m}$, wtórnie postępującą do $81,8 \mu \mathrm{m}$.

Na podstawie histologicznej oceny siatkówki, potwierdzonej badaniem OCT, wykazano, że warstwa jądrzasta wewnętrzna w oczach po przebytym ON u chorych na SM ulega zanikowi w $40 \% \mathrm{w}$ porównaniu ze zdrowymi oczami. Ponadto stopień atrofii siatkówki koresponduje z ubytkiem objętości kory [47]. Jak wykazują wyniki badań, oceniając GCL i warstwę splotowatą wewnętrzną (inner plexiform layer - IPL), można w sposób bardziej czuły przewidzieć aksonalne uszkodzenie, niż oceniając tylko RNFL [24]. Brite i wsp. w metaanalizie [48] wykazali, że GCIPL (parametr, który łączy wartość GCL i IPL) ulegał znaczącemu zmniejszeniu w oczach u chorych na SM po przebytym ON (o $16,72 \mu \mathrm{m})$, natomiast bez wywiadu ON parametr ten również malał (o $6,57 \mu \mathrm{m}$ w porównaniu z grupą kontrolną). Ścieńczenie GCL może być spowodowane subklinicznym epizodem ON, pierwotną neurodegeneracją komórek zwojowych i ich aksonów, jak również wsteczną transsynaptyczną degeneracją komórek zwojowych i ich aksonów w przebiegu uszkodzenia końcowego fragmentu drogi wzrokowej. Te wyniki potwierdzają fakt, że droga wzrokowa może być uszkodzona w przebiegu SM nawet bez występowania klinicznych objawów. Brite i wsp. [48] zaobserwowali również korelację między zmniejszeniem GCIPL a zwiększeniem niesprawności chorych, badając ich za pomocą Rozszerzonej Skali Niewydolności Ruchowej (Expanded Disability Status Scale - EDSS). Wskazuje to, że GCIPL może być dobrym markerem neurodegeneracji.

Liczne badania oceniały przydatność diagnostyczną OCT u pacjentów z udarem mózgu, ataksją rdzeniowo-móżdżkową, wrodzonymi schorzeniami OUN, obstrukcyjnym bezdechem sennym i chorobami prionowymi [49-52]. 


\section{CONCLUSIONS}

OCT is a precise, non-invasive examination that early on shows changes in the eye suggestive of a neurodegenerative disease. This method has some limitations - in neurodegenerative diseases the parameters are reduced in a non-characteristic way. Therefore, the results should not be interpreted in isolation from clinical symptoms and other neuroimaging studies. It is important to maintain a reasonable algorithm. First of all, any concomitant ocular pathologies should be identified, including cataract, glaucoma, papilloedema, short-sightedness and a history of ON [53]. The examination protocol should then include eye examination with a slit lamp, tonometry, refractometry, and at the end OCT [54]. Clinical tests of the method are still underway. Most important here are the results of a longterm follow-up which will allow for the evaluation and monitoring of physiological RNFL-th changes with age. Nevertheless, OCT may already be considered as a precise marker with which to assess the progression of neurodegenerative diseases, which may be useful in managing patients with these diseases.

\section{WNIOSKI}

Tomografia OCT jest precyzyjnym, nieinwazyjnym badaniem, które wcześnie wykazuje zmiany w oku sugerujące chorobę neurodegeneracyjną. Metoda ta ma pewne ograniczenia - w chorobach neurozwyrodnieniowych parametry ulegają zmniejszeniu w sposób niecharakterystyczny. Dlatego wyników nie powinno się interpretować w oderwaniu od objawów klinicznych i innych badań neuroobrazowych. Ważne jest zachowanie rozsądnego algorytmu postępowania. Przede wszystkim należy zidentyfikować współistniejące choroby oczu, takie jak: zaćma, jaskra, obrzęk tarczy nerwu wzrokowego, krótkowzroczność, a także zebrać wywiad w kierunku przebytego ON [53]. Protokół powinien obejmować badanie oczu w lampie szczelinowej, tonometrię, refraktometrię, a na samym końcu OCT [54]. Wciąż trwają kliniczne badania nad wykorzystaniem tej metody. Szczególnie istotne są badania długoterminowe follow-up, dzięki którym można oceniać i monitorować fizjologiczną redukcję RNFL-th wraz z wiekiem chorych. Niemniej jednak już teraz możemy uznać OCT za precyzyjny marker oceny progresji chorób neurodegeneracyjnych, który może być przydatny w prowadzeniu pacjentów z tymi chorobami.

\section{Conflict of interest/Konflikt interesu}

Absent./Nie występuje.

Financial support/Finansowanie

Absent./Nie występuje.

\section{References/Piśmiennicłwo}

1. Masland RH. The neuronal organization of the retina. Neuron 2012; 76: 266-280.

2. Thoreson WB, Mangel SC. Lateral interactions in the outer retina. Prog Retin Eye Res 2012; 31: 407-441.

3. Greenberg BM, Frohman E. Optical coherence tomography as a potential readout in clinical trials. Ther Adv Neurol Disord 2010; 3: 153-160.

4. Abtahian F, Jang IK. Optical coherence tomography: basic, current application and future potential. Curr Opin Pharmacol 2012; 12: 583-591.

5. Adgi M, Duker JS. Optical coherence tomography - current and future applications. Curr Opin Ophthalmol 2013; 24: 213-221.

6. Nelson PT, Alafuzoff I, Bigio EH, Bouras C, Braak H, Cairns NJ, et al. Correlation of Alzheimer disease neuropathologic changes with cognitive status: a review of the literature. J Neuropathol Exp Neurol 2012; 71: 362-381.

7. Chiu K, Chan TF, Wu A, Leung IY, So KF, Chang RC. Neurodegeneration of the retina in mouse models of Alzheimer's disease: what can we learn from retina? Age (Dordr) 2012; 34: 633-649.

8. Czajor K. Objawy okulistyczne w chorobie Alzheimera. Przegląd Okulistyczny 2009; 6: 1-2.

9. Blanks JC, Schmidt SY, Torigoe Y, Porrello KV, Hinton DR, Blanks RH. Retinal pathology in Alzheimer's disease. II. Regional neuron loss and glial changes in GCL. Neurobiol Aging 1996; 17: 385-395.

10. Perez SE, Lumayag S, Kovacs B, Mufson EJ, Xu S. $\beta$-amyloid deposition and functional impairment in the retina of the APPswe/PS $\Delta^{9}$ transgenic mouse model of Alzheimer's disease. Invest Ophtalmol Vis Sci 2009; 50: 793-800.

11. Jindahara P, Petrie A, Plant GT. The time course of retrograde trans-synaptic degeneration following occipital lobe damage in humans. Brain 2012; 135: 534-541.

12. Paquet C, Boissonnot M, Roger F, Dighiero P, Gil R, Hugon J. Abnormal retinal thickness in patients with mild cognitive impairment and Alzheimer's disease. Neurosci Lett 2007; 420: 97-99. 
13. He X-F, Liu Y-T, Peng C, Zhang F, Zhuang S, Zhang JS. Optical coherence tomography assessed retinal nerve fiber layer thickness in patients with Alzheimer's disease: a meta-analysis. Int J Ophthalmol 2012; 5: 401-405.

14. Iseri PK, Altinas O, Tokay T, Yüksel N. Relationship between cognitive impairment and retinal morphological and visual functional abnormalities in Alzheimer disease. J Neuroophthalmol 2006; 26: 18-24.

15. Bayhan HA, Bayhan SA, Celikbilek A, Tanik N, Gürdal C. Evaluation of the chorioretinal thickness changes in Alzheimer's disease using spectral-domain optical coherence tomography. Clin Exp Opthalmol 2015; 43: 145-151.

16. Jones-Odeh E, Hammond CJ. How strong is the relationship between glaucoma, the retinal nerve fibre layer and neurodegenerative diseases such as Alzheimer's disease and multiple sclerosis? Eye 2015; 29: 1270-1284.

17. Berisha F, Feke GT, Trempe CL, McMeel JW, Schepens CL. Retinal abnormalities in early Alzheimer's disease. Invest Ophthalmol Vis Sci 2007; 48: 2285-2289.

18. Kromer R, Serbecic N, Hausner L, Froelich L, Beutelspacher SC. Comparison of visual evoked potentials and retinal nerve fiber layer thickness in Alzheimer's disease. Front Neurol 2013; 4: 203.

19. Sergott RC, Kayabasi U. Progression of plaques in retina with dementia in Alzheimer's disease. In: 40th NANOS (North American Neuro-Ophthalmology Society) meeting, Rio Grande, Puerto Rico, USA: Annual Meeting Syllabus; 2014: 148.

20. Archibald NK, Clarke MP, Mosimann UP, Burn DJ. The retina in Parkinson's disease. Brain 2009; 132: 1128-1145.

21. Hajee ME, March WF, Lazzaro DR, Wolintz AH, Shrier EM, Glazman S, Bodis-Wollner IG. Inner retinal layer thinning in Parkinson disease. Arch Ophthalmol 2009; 127: 737-741.

22. He Q, Xu HP, Wang P, Tian N. Dopamine D1 receptors regulate the light dependent development of retinal synaptic responses. PLoS One 2013; 8: e79625.

23. Urwyler P, Nef T, Killen A, Collerton D, Thomas A, Burn D, et al. Visual complaints and visual hallucinations in Parkinson's disease. Parkinsonism Relat Disord 2014; 20: 318-322.

24. Garcia-Martin E, Larrosa JM, Polo V, Satue M, Marques ML, Alarcia R, et al. Distribution of retinal layer atrophy in patients with Parkinson disease and association with disease severity and duration. Am J Ophthalmol 2014; 157: 470-478.

25. Yu JG, Feng YF, Xiang Y, Huang JH, Savini G, Parisi V, et al. Retinal nervefiber layer thickness changes in Parkinson disease: a meta-analysis. PLoS One 2014; 9: e85718.

26. Tsironi EE, Dastiridou A, Katsanos A, Dardiotis E, Veliki S, Patramani G, et al. Perimetric and retinal nerve fiber layer findings in patients with Parkinson's disease. BMC Ophthalmol 2012; 12: 54.

27. Schneider M, Müller HP, Lauda F, Tumani H, Ludolph AC, Kassubek J, et al. Retinal single-layer analysis in Parkinsonian syndromes: an optical coherence tomography study. J Neural Transm 2014; 121: 41-47.

28. Shrier EM, Adam CR, Spund B, Glazman S, Bodis-Wollner I. Interocular asymmetry of foveal thickness in Parkinson disease. J Ophthalmol 2012; 2012: 728457.

29. Altintas O, Iseri P, Ozkan B, Caglar Y. Correlation between retinal morphological and functional findings and clinical severity in Parkinson's disease. Doc Ophthalmol 2008; 116: 137-146.

30. Satue M, Seral M, Otin S, Alarcia R, Herrero R, Bambo MP, et al. Retinal thinning and correlation with functional disability in patients with Parkinson's disease. Br J Ophthalmol 2014; 98: 350-355.

31. Ahn J, Lee JY, Kim TW, et al. Retinal thinning correlates with nigral dopaminergic loss in de novo Parkinson disease. Neurology 2018; 91: e1003-e1012.

32. Petzold A, Wattjes MP, Costello F, et al. The investigation of acute optic neuritis neuritis: a review and proposed protocol. Nat Rev Neurol 2014; 10: 447-458.

33. Parisi V, Manni G, Spadaro M, Colacino G, Restuccia R, Marchi S, et al. Correlation between morphological and functional retinal impairment in multiple sclerosis patients. Invest Ophthalmol Vis Sci 1999; 40: 2520-2527.

34. Costello F, Hodge W, Pan YI, Eggenberger E, Freedman MS. Using retinal architecture to help characterize multiple sclerosis patients. Can J Ophthalmol 2010; 45: 520-526.

35. Balcer LJ. Clinical trials to clinical use: using vision as a model for multiple sclerosis and beyond. J Neuroophthalmol 2014; 34 (Suppl): S18-S23.

36. Trip SA, Schlottmann PG, Jones SJ, Altmann DR, Garway-Heath DF, Thompson AJ, et al. Retinal nerve fiber layer axonal loss and visual dysfunction in optic neuritis. Ann Neurol 2005; 58: 383-391.

37. Kupersmith MJ, Mandel G, Anderson S, et al. Baseline, one and three month changes in the prepapillary retinal nerve fiber layer in acute optic neuritis: relations to baseline vision and MRI. J Neurol Sci 2011; 308: 117-123.

38. Kallenbach K, Simonsen H, Sander B, et al. Retinal nerve fiber layer thickness is associated with lesion length in acute optic neuritis. Neurology 2010; 74: 252-258.

39. Ikuta F, Zimmerman HM. Distribution of plaques in seventy autopsy cases of multiple sclerosis in the United States. Neurology 1976; 26: 26-28.

40. Toussaint D, Perier O, Verstappen A, Bervoets S. Clinicopathological study of the visual pathways, eyes and cerebral hemispheres in 32 cases of disseminated sclerosis. J Clin Neuroophthalmol 1983; 3: 211-220.

41. Petzold A, de Boer JF, Schippling S, et al. Optical coherence tomography in multiple sclerosis: a systematic review and meta-analysis. Lancet Neurol 2010; 9: 921-932.

42. Gundogan FC, Demirkaya S, Sobaci G. Is optical coherence tomography really a new biomarker candidate in multiple sclerosis? - A structural and functional evaluation. Invest Ophthalmol Vis Sci 2007; 48: 5773-5781.

43. Costello F, Coupland S, Hodge W, Lorello GR, Koroluk J, Pan YI, et al. Quantifying axonal loss after optic neurotis with optical coherence tomography. Ann Neurol 2006; 59: 963-969.

44. Huang J, Dai H, Zhang H, Wang X, Chen T. Clinical investigation of optic coherence tomography in evaluating the impairment of optic nerve secondary to multiple sclerosis. Zhonghua Yan Ke Za Zhi 2014; 50: 900-905. 
45. Feng L, Shen J, Jin X, Li J, Li Y. The evaluation of the retinal nerve fiber layer in multiple sclerosis with specialdomain optical coherence tomography. Ophthalmologica 2013; 230: 116-120.

46. Pulicken M, Gordon-Lipkin E, Balcer LJ, Frohman E, Cutter G, Calabresi PA. Optical cohrence tomography and disease subtype in multiple sclerosis. Neurology 2007; 69: 2085-2092.

47. Green AJ, McQuaid S, Hauser SL, Allen, Lyness R. Ocular pathology in multiple sclerosis: retinal atrophy and inflammation irrespective of disease duration. Brain 2010; 133: 1591-1601.

48. Britze J, Pihl-Jensen G, Frederiksen Lautrup J. Retinal ganglion cell analysis in multiple sclerosis and optic neuritis : a systematic review and meta-analysis. J Neurol 2017; 264: 1837-1853.

49. Pula JH, Towle VL, Staszak VM, Cao D, Bernard JT, Gomez CM. Retinal nerve fibre layer and macular thinning in spinocerebellar ataxia and cerebellar multisystem atrophy. Neuroophthalmology 2011; 35: 108-114.

50. Wiethoff S, Zhour A, Schöls L, Fischer MD. Retinal nerve fibre layer loss in hereditary spastic paraplegias is restricted to complex phenotypes. BMC Neurol 2012; 12: 143.

51. Wang D, Li Y, Wang C, Xu L, You QS, Wang YX, et al. Localized retinal nerve fiber layer defects and stroke. Stroke 2014; 45: 1651-1656.

52. Kopishinskaya S, Svetozarskiy S, Antonova V, Gustov A. The first data on retinal optical coherence tomography parameters in Huntington's disease. Eur J Neurol 2014; 21 (Suppl 1): 36.

53. Bambo MP, Garcia-Martin E, Otin S, Sancho E, Fuertes I, Herrero R, et al. Influence of cataract surgery on repeatability and measurements of spectral domain optical coherence tomography. Br J Ophthalmol 2014; 98: 52-58.

54. Rao HL, Addepalli UK, Yadav RK, Senthil S, Choudhari NS, Garudadri CS. Effect of scan quality on diagnostic accuracy of spectra-domain optical coherence tomography in glaucoma. Am J Ophthalmol 2014; 157: 719-727. 